\title{
Peroxovanadate and insulin action in adipocytes from NIDDM patients. Evidence against a primary defect in tyrosine phosphorylation
}

\author{
Z .-W. Y u ${ }^{1,2}$, P.-A . Jansson ${ }^{1}$, B. I. Posner ${ }^{3}$, U . Smith ${ }^{1}$, J. W. E riksson ${ }^{1,2}$ \\ ${ }^{1}$ The Lundberg Laboratory for Diabetes Research, Department of Medicine, University of Göteborg, Sahlgrenska University \\ Hospital, Göteborg, Sweden \\ ${ }^{2}$ Department of Medicine, University of Umeå, Norrland University Hospital, Umeå, Sweden \\ ${ }^{3}$ Department of Medicine, McGill University, Montreal, Canada
}

Summary We studied the effects of insulin and the stable peroxovanadate compound potassium bisperoxopicolinatooxovanadate (bpV(pic)), a potent inhibitor of phosphotyrosine phosphatases, on lipolysis and glucose uptake in subcutaneous adipocytes from 10 male patients with non-insulin-dependent diabetes mellitus (NIDDM) and 10 matched non-diabetic control subjects. Lipolysis stimulated by isoprenaline or the cAMP analogue, 8-bromo-cyclic AMP (8-brcAMP), was reduced by approximately $40 \%$ in NIDDM compared to control subjects. In both groups $\mathrm{bpV}$ (pic) exerted an antilipolytic effect that was similar to insulin $(\sim 50 \%$ inhibition $) .{ }^{14} \mathrm{C}$-U-glucose uptake was dose-dependently increased by $\mathrm{bpV}($ pic $)$ treatment, but this effect and also that of insulin were impaired in NIDDM compared to control (bpV(pic) 1.6-fold vs 2.4-fold and insulin 2.2-fold vs 3.4-fold). Furthermore, low concentrations of $\mathrm{bpV}$ (pic) did not affect insulin-stimulated glucose uptake, although tyrosine phosphorylation of the insulin receptor $\beta$ subunit was clearly increased by bpV(pic). In conclusion, 1) $\beta$-adrenergic stimulation of lipolysis in vitro is attenuated in NIDDM adipocytes due to post-receptor mechanisms. 2) Both insulin and bpV(pic) decrease lipolysis and enhance glucose uptake in control as well as NIDDM adipocytes. The effect on glucose uptake, but not that on lipolysis, is impaired in NIDDM cells. 3) Peroxovanadate does not improve sensitivity and responsiveness to insulin in NIDDM adipocytes, showing that insulin-resistant glucose uptake in NIDDM is not overcome by phosphotyrosine-phosphatase inhibition and, thus, probably is not caused by impaired tyrosine phosphorylation events alone. [Diabetologia (1997) 40: 1197-1203]

Keywords Peroxovanadate, insulin, isoprenaline, cAMP, lipolysis, glucose uptake, tyrosine phosphorylation, NIDDM, adipocyte, in vitro.
In the search for effective treatments for diabetes mellitus, vanadium compounds have been found to exert pronounced insulinomimetic effects [1]. These

Received: 28 October 1996 and in revised form: 13 May 1997

Corresponding author: Dr. Z.-W. Yu, Department of Medicine, University of Umeå, Norrland University Hospital, S-901 85 Umeå, Sweden

A bbreviations: ADA, Adenosine deaminase; bpV(pic), potassium bisperoxopicolinatooxovanadate; 8-br-cAMP, 8-bromocyclic AMP; BSA, bovine serum albumin; cGI-PDE, cGMPinhibitable phosphodiesterase; ECL, enhanced chemiluminescence; IRS-1, insulin receptor substrate-1; NIDDM, non-insulin-dependent diabetes mellitus; PTP, phosphotyrosine phosphatase; PIA, $\mathrm{N}^{6}$-(R-phenylisopropyl) adenosine; $\mathrm{pV}$, peroxovanadate. include the normalization of perturbations in glucose metabolism in diabetic animals $[2,3]$. Recently, a similar effect was also reported in non-insulin-dependent diabetic subjects [4]. In addition to their insulin-like effects, these compounds can also amplify insulin action and improve insulin resistance $[1$, 5-7]. Moreover, since insulin signalling involves tyrosine phosphorylation at several levels, the ability of vanadium compounds to inhibit phosphotyrosine phosphatases (PTP) has been widely used to elucidate mechanisms of insulin action $[8,9]$. In spite of extensive studies in animals, the cellular action of vanadium compounds in humans, both healthy and insulin-resistant, still needs to be further clarified. This was also suggested by work in our laboratory showing that peroxovanadate $(\mathrm{pV})$, but 
Table 1. Clinical and laboratory features of subjects

\begin{tabular}{lccl}
\hline & NIDDM $(\mathrm{n}=10)$ & Control $(\mathrm{n}=10)$ & $\mathrm{p}$ value \\
\hline Age $($ years $)$ & $52 \pm 2(42-61)$ & $50 \pm 2(41-65)$ & NS \\
BMI $\left(\mathrm{kg} / \mathrm{m}^{2}\right)$ & $27.5 \pm 1.2(21.3-32.3)$ & $27.7 \pm 1.2(23.0-32.2)$ & NS \\
Waist/hip ratio $_{\mathrm{HbA}_{1 \mathrm{c}}(\%)^{\mathrm{a}}}$ & $0.96 \pm 0.02(0.85-1.06)$ & $1.00 \pm 0.02(0.88-1.08)$ & NS \\
Cell diameter $(\mu \mathrm{m})$ & $6.8 \pm 0.3(5.4-9.1)$ & $5.0 \pm 0.1(4.4-5.5)$ & $<0.005$ \\
\hline
\end{tabular}

Data are mean \pm SEM and (range)

${ }^{a}$ Normal range $3.3-5.3 \%$

not vanadate, has insulin-like effects in human adipocytes [10].

Diabetes is typically characterized by hyperglycaemia and is often associated with hyperlipidaemia, i.e. high levels of non-esterified fatty acids and triglycerides [11]. A failing insulin effect on glucose uptake and lipolysis in insulin-sensitive tissues may be partly responsible for these abnormalities. However, previous studies suggest that glucose uptake and lipolysis are not equally involved in cellular insulin resistance $[12,13]$. Resistance to the antilipolytic effect of the insulin in NIDDM is not a consistent finding [12,14-16]. Among possible cellular mechanism causing insulin resistance in diabetes, an impaired tyrosine phosphorylation of the insulin receptor has been suggested as being important. This is mainly based on the observed association between impairments in tyrosine phosphorylation and insulin action [17]. In order to further evaluate the causality, a direct reversal of the impaired tyrosine phosphorylation in order to observe the consequence is another possible approach. In this study we investigated the effects of insulin and the stable peroxovanadate compound $\mathrm{bpV}$ (pic) [8] on lipolysis and glucose uptake in adipocytes from NIDDM patients. Since bpV(pic) causes a potent tyrosine phosphorylation of cellular proteins [18], its effects on insulin action with respect to glucose uptake in NIDDM adipocytes were also examined.

\section{Subjects, materials and methods}

$\left[{ }^{14} \mathrm{C}\right] \mathrm{U}-\mathrm{D}$-glucose (specific activity $246 \mu \mathrm{Ci} / \mu \mathrm{mol}$ ) and $\mathrm{ECL}$ (enhanced chemiluminescence) kit together with a monoclonal horseradish peroxidase-labelled antibody were purchased from Amersham (Amersham, Bucks., UK). $\left[\gamma_{-}{ }^{32} \mathrm{P}\right] \mathrm{ATP}$ (specific activity $3 \mathrm{Ci} / \mu \mathrm{mol}$ ) was from Du Pont (Geneva, Switzerland). Isoprenaline, 8-br-cAMP, bovine serum albumin (BSA; fraction V) and collagenase were from Sigma Chemical Co. (St. Louis, Mo., USA). Adenosine deaminase (ADA), $\mathrm{N}^{6}-(\mathrm{R}$ phenylisopropyl) adenosine (PIA) and glycerokinase were from Boehringer Mannheim (Mannheim, Germany). Medium 199 was obtained from Gibco BRL, Life Technologies (Paisley, UK). A monoclonal mouse antiphosphotyrosine antibody was from UBI (Lake Placid, N. Y., USA). Human monocomponent insulin was purchased from Novo Nordisk (Copenhagen, Denmark). bpV(pic) was prepared as previously reported [8] and was kindly provided by Dr. Alan Shaver (Department of Chemistry, McGill University, Montreal, Canada).
Subjects. We recruited 10 male NIDDM patients in good metabolic control and 10 male non-diabetic control subjects matched pairwise for age and body mass index. The major clinical and laboratory features of subjects are given in Table 1 . In each group there were six obese subjects (body mass index $>27 \mathrm{~kg}$ / $\mathrm{m}^{2}$ ). The average duration of diabetes was $3.3 \pm 1.6$ years. The NIDDM subjects were treated with diet alone $(n=2)$ or together with oral antidiabetic medication $(n=8$; sulphonylurea 5, metformin 1, both 2). No patient was treated with insulin. All patients had normal blood pressure, kidney and liver function and they had no endocrine disease other than diabetes. All participating subjects gave their informed consent, and the study was approved by the ethics committee of the University of Göteborg.

Needle biopsies and isolation of adipocytes. Needle biopsies $(\sim 2 \mathrm{~g})$ of abdominal subcutaneous fat tissue were performed after breakfast at 08.00-09.00 hours. The fat tissue was washed with prewarmed medium 199 and adipocytes were isolated in medium containing $0.6 \mathrm{mg} / \mathrm{ml}$ collagenase and $4 \%$ BSA at $37^{\circ} \mathrm{C}$ for $1 \mathrm{~h}$ in a shaking water bath $(\sim 120 \mathrm{rpm})$ and subsequently filtered through a nylon mesh. The adipocytes were again washed with fresh medium four times. The entire procedure lasted for approximately $1.5 \mathrm{~h}$ and short-term effects of insulin and other hormones present in vivo should be eliminated. Cell size and number were determined as previously reported [19].

L ipolysis. Isolated cells were incubated at lipocrit 1-3\% in medium 199 containing $5.6 \mathrm{mmol} / \mathrm{l}$ glucose, $4 \%$ BSA, ADA $(1 \mathrm{U} / \mathrm{ml})$ and PIA $(1 \mu \mathrm{mol} / \mathrm{l})$ and the indicated agents at $37^{\circ} \mathrm{C}$ for $1 \mathrm{~h}$. The incubation was stopped by cooling on ice and adipocytes were rapidly separated from medium by centrifugation through silicone oil. Lipolysis was assessed by determining the glycerol content in the medium according to Bradley and Kaslow [20]. Briefly, glycerol was phosphorylated in the presence of glycerokinase and $\left[\gamma_{-}{ }^{32} \mathrm{P}\right] \mathrm{ATP}$ at $37^{\circ} \mathrm{C}$ for $30 \mathrm{~min}$. Residual $\left[\gamma-{ }^{32} \mathrm{P}\right]$ ATP was then hydrolysed in perchloric acid at $95^{\circ} \mathrm{C}$ for $1 \mathrm{~h}$. Free $\left[{ }^{32} \mathrm{P}\right]$ phosphate was precipitated on ice in the presence of ammonium molybdate and triethylamine. After centrifugation, radioactivity of the supernatant (reflecting phosphorylated glycerol) was measured.

G lucose uptake. For glucose uptake assessment, adipocytes (lipocrit $3-5 \%$ ) were preincubated as above but in medium without glucose for $15 \mathrm{~min}$ at $37^{\circ} \mathrm{C}$ in the presence or absence of $\mathrm{bpV}$ (pic) and/or insulin and subsequently ${ }^{14} \mathrm{C}$-U-D-glucose $(0.86 \mu \mathrm{mol} / \mathrm{l})$ was added. After $1 \mathrm{~h}$ the glucose uptake was terminated by transferring cells and medium to prechilled tubes on ice. Adipocytes were then immediately separated by centrifugation through silicone oil. Cell-associated radioactivity was determined and remaining extracellular ${ }^{14} \mathrm{C}-\mathrm{U}-\mathrm{D}$-glucose, assessed by adding the same amount of the isotope at the end of incubation, was subtracted. The cellular clearance of glucose 
from the medium was calculated according to the following formula and taken as an index of the rate of glucose uptake.

Cellular clearance of medium glucose $=$

cpm cells

$\overline{\text { cpm medium } \times \text { cell number } \times \mathrm{s}}$

Western blots of phosphotyrosine-containing proteins. The procedure was essentially performed as previously described [18]. Briefly, after the preincubation of cells with the indicated agents in medium 199 at $37^{\circ} \mathrm{C}$ for $15 \mathrm{~min}$, the cells were separated from medium and lysed at $4^{\circ} \mathrm{C}$ for $1 \mathrm{~h}$ in a solution containing $25 \mathrm{mmol} / \mathrm{l}$ Tris-HCI, $0.5 \mathrm{mmol} / \mathrm{l}$ EDTA, $25 \mathrm{mmol} / \mathrm{l} \mathrm{NaCl}, 1 \%$ $\mathrm{NP}-40,10 \mathrm{mmol} / \mathrm{l} \mathrm{NaF}, 0.2 \mathrm{mmol} / \mathrm{l}$ leupeptin, $1 \mathrm{mmol} / \mathrm{l}$ benzamidine, $2 \mathrm{mmol} / \mathrm{l}$ 4-(2-aminoethyl)-benzene sulphonylfluoride and $1 \mathrm{mmol} / \mathrm{l}$ sodium orthovanadate during vigorous rocking. Proteins $(15 \mu \mathrm{g} / \mathrm{lane})$ in whole cell lysates were separated by electrophoresis on a $10 \%$ SDS-polyacrylamide gel, transferred to a nitrocellulose membrane and immunoblotted with a monoclonal antiphosphotyrosine antibody and a secondary horseradish peroxidase-labelled antibody. Immunoreactive proteins were visualized using the ECL kit and autoradiography films. The apparent molecular weights of the phosphopeptides were determined by comparison with protein standards.

Statistical analysis. Statistical significance of differences was tested with Student's two-tailed t-test for paired data. Results are means \pm SEM unless otherwise indicated.

\section{Results}

L ipolysis. Basal lipolysis was not different between the NIDDM and control groups (glycerol release per hour $1.3 \pm 0.3$ vs $1.1 \pm 0.3 \mathrm{nmol} / 10^{5}$ cells). In contrast, lipolysis stimulated with a high concentration of isoprenaline $(1 \mu \mathrm{mol} / \mathrm{l})$ or 8 -br-cAMP $(10 \mathrm{mmol} / \mathrm{l})$ was reduced by approximately $40 \%$ in NIDDM compared to control subjects (Fig.1. Isoprenaline: $995 \pm 288 \%$ of basal lipolysis for NIDDM vs $1586 \pm$ $346 \%$ for control, $n=8$. 8-br-cAMP: $1540 \pm 238 \%$ for NIDDM vs $2743 \pm 415 \%$ for control, $n=10$ ).

In the presence of $5 \mathrm{mmol} / \mathrm{l}$ 8-br-cAMP both bpV(pic) $(0.01-1 \mathrm{mmol} / \mathrm{l})$ and insulin $(0.6-600 \mathrm{pmol} /$ l) exerted a clear and similar concentration-dependent antilipolytic effect both in NIDDM and control cells (Fig.2A and B). The maximal effects of $\mathrm{bpV}(\mathrm{pic})(1 \mathrm{mmol} / \mathrm{l})$ and insulin $(600 \mathrm{pmol} / \mathrm{l})$ tended to be smaller in the NIDDM group than in control subjects, but this difference was not statistically significant $(41 \pm 12$ vs $57 \pm 6 \%$ inhibition for $\mathrm{bpV}$ (pic) and $53 \pm 16$ vs $65 \pm 12 \%$ for insulin, $n=9, N S$ ).

$\mathrm{bpV}$ (pic) also displayed a clear antilipolytic effect $(\sim 50 \%$ inhibition $)$ in the presence of a stable, nondegradable cAMP analogue, $\mathrm{N}^{6}$-monobutyryl cAMP, in adipocytes from NIDDM patients (data not shown), similar to what was previously seen in control cells [18].

G lucose uptake. Basal ${ }^{14} \mathrm{C}$-U-glucose uptake in adipocytes was not different between the two groups

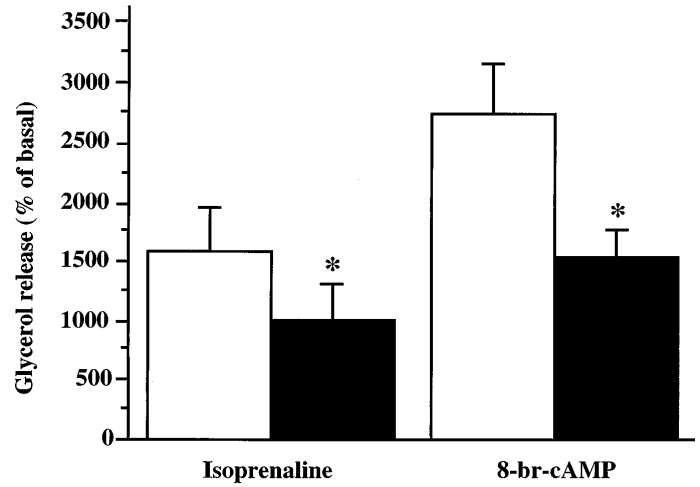

Fig. 1. Effects of isoprenaline and 8-br-cAMP on lipolysis in adipocytes from control subjects $(\square)$ and NIDDM patients (П). Isolated cells were incubated in medium containing $4 \%$ BSA, ADA $(1 \mathrm{U} / \mathrm{ml})$ and PIA $(1 \mu \mathrm{mol} / \mathrm{l})$ for $1 \mathrm{~h}$ at $37^{\circ} \mathrm{C}$ in the presence or absence of isoprenaline $(1 \mu \mathrm{mol} / \mathrm{l})$ and 8 -brcAMP $(10 \mathrm{mmol} / \mathrm{l})$ as indicated. The glycerol content in the medium was subsequently measured. Data (means \pm SEM) are from $8-10$ separate experiments. $p<0.05$ for comparisons between NIDDM and control adipocytes
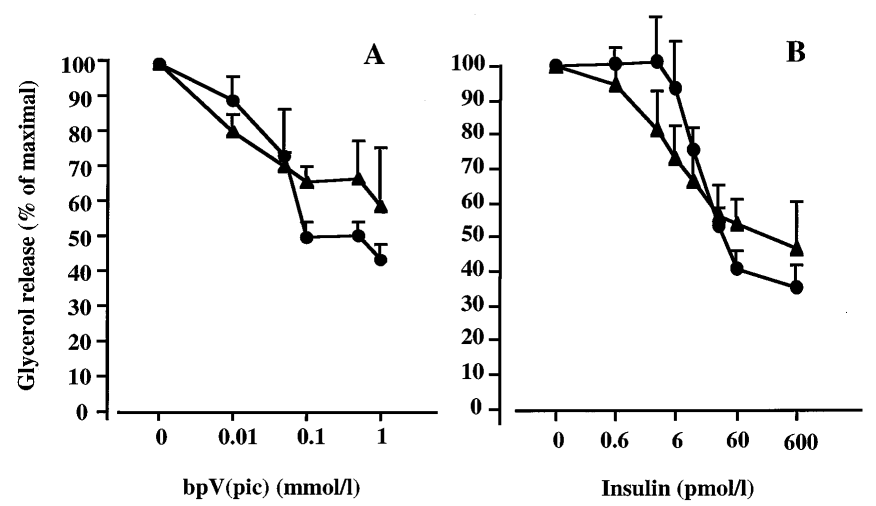

Fig. 2. A, B Dose-response curves for the antilipolytic effects of $\mathrm{bpV}$ (pic) and insulin on lipolysis in adipocytes from control $(\boldsymbol{O})$ and NIDDM patients $(\boldsymbol{\Delta})$. Isolated cells were incubated as in Figure 1 but in the presence of 8 -br-cAMP $(5 \mathrm{mmol} / \mathrm{l})$ and the indicated concentrations of $\mathrm{bpV}$ (pic) (A) or insulin (B). The glycerol content in the incubation medium was subsequently measured. Data (means \pm SEM) are from 7-10 separate experiments and are expressed as glycerol release (percent of the maximal, unopposed glycerol release). The absolute values for glycerol release per hour ( $\mathrm{nmol} / 10^{5}$ cells) were in control cells: for $5 \mathrm{mmol} / 1$ 8-br-cAMP alone $16.1 \pm 2.7$; plus $600 \mathrm{pmol} / \mathrm{l}$ insulin $6.6 \pm 1.7$ or plus $1 \mathrm{mmol} / \mathrm{l} \mathrm{bpV(pic)} 7.3 \pm 1.9$ and in NIDDM cells: 8 -br-cAMP alone $13.1 \pm 2.7$; plus 600 $\mathrm{pmol} / \mathrm{l}$ insulin $6.3 \pm 1.1$ or plus $1 \mathrm{mmol} / \mathrm{l} \mathrm{bpV}$ (pic) $7.4 \pm 1.3$

$\left(12.2 \pm 2.1\right.$ vs $12.3 \pm 2.5 \mathrm{fl} \cdot$ cell $^{-1} \cdot \mathrm{s}^{-1}$ for NIDDM vs control). bpV(pic) increased glucose uptake both in control and NIDDM cells in a concentration-dependent manner, but at high concentrations $(0.5 \mathrm{mmol} / \mathrm{l}$ or higher) this effect was attenuated and was completely absent at $5 \mathrm{mmol} / \mathrm{l}$ (Fig. 3). Thus, the previously reported [18] biphasic dose-response curve for $\mathrm{bpV}$ (pic) action in normal cells was also found in the NIDDM cells and there were no consistent 


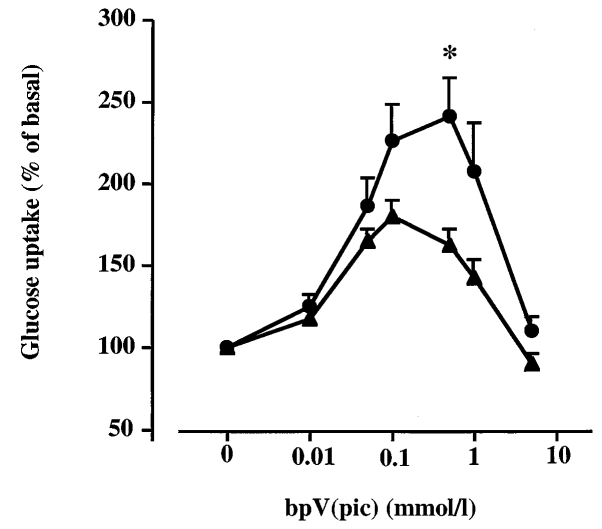

Fig. 3. Dose-response curves for the effects of $\mathrm{bpV}(\mathrm{pic})$ on glucose uptake in adipocytes from control (O) and NIDDM patients $(\boldsymbol{\Delta})$. Isolated cells were preincubated at $37^{\circ} \mathrm{C}$ for $15 \mathrm{~min}$ with ADA $(1 \mathrm{U} / \mathrm{ml})$, PIA $(1 \mu \mathrm{mol} / \mathrm{l})$ and the indicated concentrations of $\mathrm{bpV}(\mathrm{pic})$ in medium containing $4 \%$ BSA without glucose. ${ }^{14} \mathrm{C}-\mathrm{U}$-D-glucose was then added. After $1 \mathrm{~h}$ the cell-associated radioactivity was determined. Data are means \pm SEM and were obtained from 7-9 separate experiments. $* p<0.05$ compared to the corresponding point of the NIDDM group

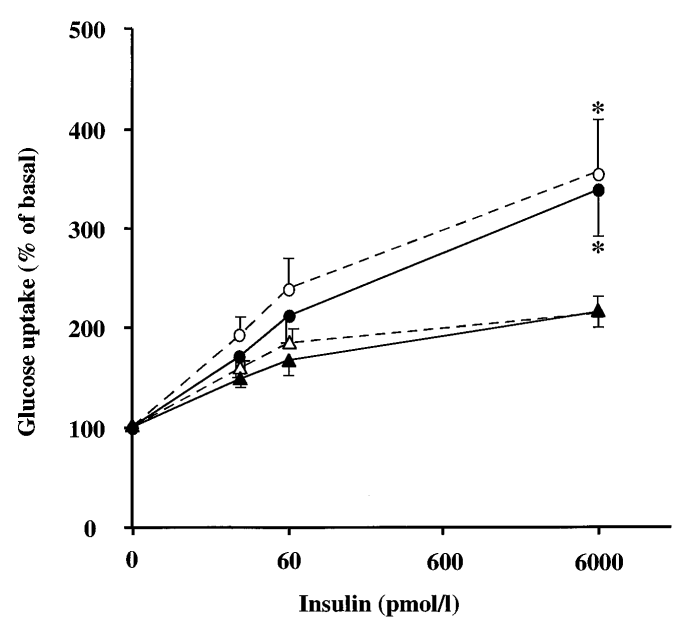

Fig. 4. Effects of $\mathrm{bpV}$ (pic) on insulin-stimulated glucose uptake in adipocytes from control $(\bigcirc)$ and NIDDM patients $(\Delta \triangle)$. Isolated cells were preincubated as in Figure 3 but with the indicated concentrations of insulin in the absence $(\Delta \Delta)$ or presence $(\bigcirc \triangle) 0.01 \mathrm{mmol} / \mathrm{l} \mathrm{bpV}($ pic $)$. Data are means \pm SEM of $8-9$ separate experiments. $* p<0.05$ compared to the corresponding point of the NIDDM group

differences between the groups in this respect. However, as shown in Figure 3, the effect of $\mathrm{bpV}$ (pic) was clearly impaired in adipocytes from NIDDM patients compared to that in control cells $(0.5 \mathrm{mmol} / 1$ bpV(pic): $162 \pm 9$ vs $241 \pm 24 \%$ of basal glucose uptake, $n=7, p<0.05)$. The maximal insulin-stimulated glucose uptake was also reduced in NIDDM adipocytes compared to the control group (Fig. 4, $6 \mathrm{nmol} / \mathrm{l}$ insulin: $216 \pm 16$ vs $338 \pm 46 \%$ of basal glucose uptake, $n=9, p<0.05)$. In the presence of a low concentration of $\mathrm{bpV}(\mathrm{pic})(0.01 \mathrm{mmol} / \mathrm{l})$ the effect of insulin on glucose uptake was not consistently altered in either group (Fig.4) and neither insulin sensitivity nor the maximal response was affected. This was

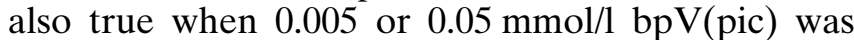
used (data not shown).

Protein tyrosine phosphorylation in adipocytes from NID D M patients. Adipocytes obtained from NIDDM patients were preincubated with $\mathrm{bpV}$ (pic) alone or in combination with insulin. The cells were subsequently lysed and protein tyrosine phosphorylation was examined by immunoblots. bpV(pic) alone (0.005$0.05 \mathrm{mmol} / \mathrm{l})$ markedly increased tyrosine phosphorylation of the insulin receptor $\beta$-subunit $(\sim 5-15$-fold increase compared to basal) and several other proteins including insulin receptor substrate-1 (IRS-1) in a concentration-dependent manner (Fig. 5A). It also clearly amplified insulin-induced tyrosine phosphorylation of the insulin receptor $\beta$-subunit ( $\sim 3-6$ fold increase compared to $0.3 \mathrm{nmol} / \mathrm{l}$ insulin treatment alone which caused $\sim 2$-fold increase compared to basal) and other proteins (Fig.5A). In addition, the effect of insulin at different concentrations was also assessed. Insulin $(0.06-6 \mathrm{nmol} / \mathrm{l})$ mainly stimulated tyrosine phosphorylation of the insulin receptor $\beta$ subunit $(\sim 95 \mathrm{kDa})$ as well as IRS-1 $(\sim 185 \mathrm{kDa})$ in a concentration-dependent manner (Fig. 5B). The insulin effect in all tested concentrations was again amplified in the presence of $\mathrm{bpV}$ (pic) by $\sim 2-3$-fold. Concomitant glucose uptake experiments using adipocytes from the same NIDDM subjects confirmed that insulin-stimulated glucose uptake (full dose-response curve) was not enhanced in the presence of these concentrations of $\mathrm{bpV}(\mathrm{pic}$ ) (data not shown and Fig.4). Corresponding experiments with cells from control subjects showed that the effect of $\mathrm{bpV}$ (pic) on tyrosine phosphorylation of the insulin receptor $\beta$-subunit, both in the presence or absence of insulin, was very similar to that found in adipocytes from NIDDM patients (data not shown). This is in agreement with previously reported results $[8,18]$.

\section{Discussion}

An important topic in NIDDM pathophysiology is the regulation of lipolysis in adipose tissue. The present data clearly show an impairment in the $\beta$-adrenergic activation of lipolysis in adipocytes from NIDDM patients when compared to cells from strictly matched control subjects. Since the non-selective $\beta$-adrenergic receptor agonist isoprenaline as well as the degradable cAMP analogue 8-br-cAMP stimulated lipolysis to a lesser degree in NIDDM than in control cells, this impairment is located at the post-receptor level, probably downstream cAMP formation, e.g. involving protein kinase A or hormone-sensitive 

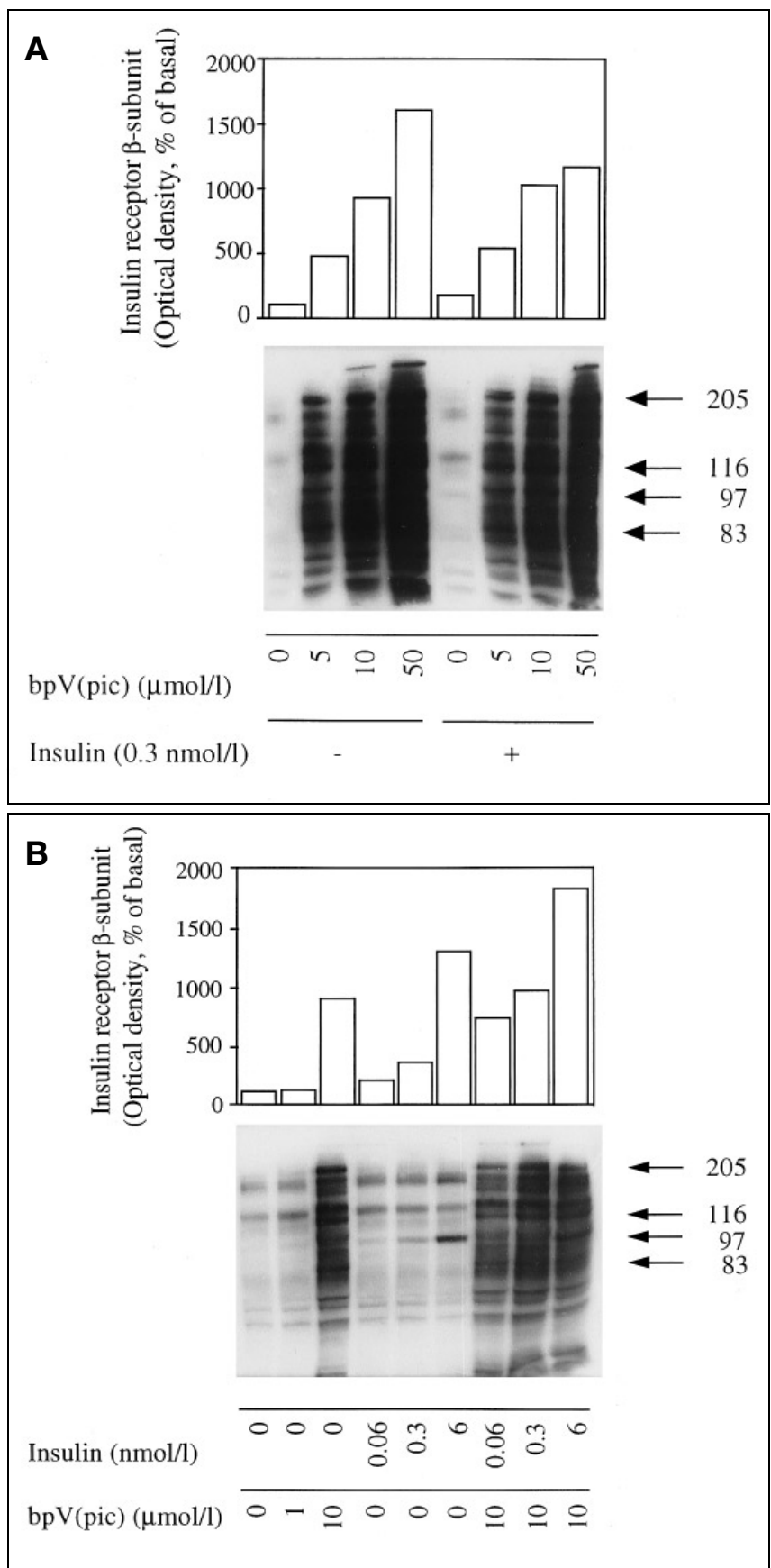

Fig. 5. A , B Effects of bpV(pic) and insulin on in situ tyrosine phosphorylation of proteins in adipocytes from NIDDM patients. Isolated adipocytes were preincubated at $37^{\circ} \mathrm{C}$ for 15 min with the indicated agents in medium 199, and the cells were then lysed. Proteins $(15 \mu \mathrm{g} / \mathrm{lane})$ of whole cell lysates were separated by electrophoresis on a $10 \%$ SDS-polyacrylamide gel, transferred to nitrocellulose membranes and immunoblotted with a monoclonal antiphosphotyrosine antibody as described in "Subjects and Methods". A : Concentration-dependent effect of $\mathrm{bpV}$ (pic) on tyrosine phosphorylation in the absence or presence of insulin; B : Concentration-dependent effect of insulin on tyrosine phosphorylation in the absence or presence of $\mathrm{bpV}$ (pic). The upper panel in $\mathbf{A}$ and $\mathbf{B}$ shows the relative density of the corresponding insulin receptor $\beta$-subunit bands $(\sim 95 \mathrm{kDa})$ quantified with a laser densitometer and the density values were adjusted for local background. IRS$1 \sim 185 \mathrm{kDa}$. One representive experiment from four separate experiments with similar results is shown lipase [21]. Interestingly, a blunted activation of lipolysis in vitro has also been found in insulin-resistant patients with abdominal obesity [22] and also in other states associated with insulin resistance such as familial combined hyperlipidaemia [23].

Being a potent PTP inhibitor [8], peroxovanadate $(\mathrm{pV})$ is interesting as a potential agent for the treatment of diabetes $[1,4]$. The present study in vitro demonstrated that $\mathrm{bpV}$ (pic) exerted a marked inhibition of lipolysis in NIDDM adipocytes, similar to that in cells of control subjects. The mechanisms for the antilipolytic effect of $\mathrm{pV}$ have not been completely clarified. There is evidence indicating that cAMP degradation via the cGMP-inhibitable phosphodiesterase (cGI-PDE) is important for the antilipolytic effect of vanadate [24], similar to that of insulin [25, 26]. However, this cannot be the sole mechanism for the effect of $\mathrm{pV}$ since also lipolysis stimulated by the non-degradable cAMP analogue, $\mathrm{N}^{6}$-monobutyryl cAMP, was inhibited by $b p V($ pic) as was also previously reported in cells from control subjects [18]. Thus, the finding that $\mathrm{bpV}$ (pic) exerted an equivalent antilipolytic effect in NIDDM and control cells may suggest that both cGI-PDE and additional mechanisms involved in antilipolysis are intact in NIDDM adipocytes.

Furthermore, the antilipolytic effect of insulin was not clearly impaired in NIDDM adipocytes suggesting that this action of insulin is not primarily perturbed at the cellular level as also proposed by an earlier study [12]. These results also suggest that the effect of insulin to increase cGI-PDE activity, which is a central mechanism for its antilipolytic effect $[25,26]$, is not impaired. However, these results do not exclude the possibility of an impaired antilipolytic effect of insulin in vivo due to the complex regulation of ambient lipolysis with several interacting neural, hormonal and cellular events [27, 28]. Previous reports regarding the antilipolytic effect of insulin both in vitro and in vivo in diabetes are quite controversial, probably due to the differences in patient selection, treatment regimens, metabolic control and methodology [14-16].

$\mathrm{bpV}$ (pic) exerted a clear effect on glucose uptake, but this effect, similar to that of insulin, was apparently impaired in cells from diabetic patients. Since $p V$ acts at the post-insulin-binding level in human fat cells [18], post-binding defects as well as a reduced amount of glucose transporter GLUT4 [29] are possible explanations for this abnormality. Furthermore, the impairment in glucose uptake stimulation for both $\mathrm{pV}$ and insulin suggests that they share common signalling pathways as does the finding that $\mathrm{pV}$ was unable to overcome insulin resistance. These findings may also suggest that the impairment of the insulin effect on glucose uptake, in contrast to the intact antilipolytic effect of insulin, is an intrinsic defect in adipocytes from diabetic patients. However, this is not necessarily a primary event but could also be secondary to the diabetic state. 
The blunted insulin effect on glucose uptake in peripheral insulin-sensitive tissues including fat is a common finding in NIDDM patients [17]. According to previous results, an underlying mechanism in adipocytes may be the impaired ability of insulin to stimulate tyrosine phosphorylation of insulin-signalling proteins including the insulin receptor itself [17, 30, 31]. Such an impairment in tyrosine phosphorylation is expected to result in a decreased insulin sensitivity vis-à-vis glucose transport activation, whereas the maximal insulin response could be left intact due to "spare tyrosine kinase capacity" [30]. However, the present data clearly show a potent enhancing effect of $\mathrm{pV}$ on insulin-stimulated protein phosphorylation without any accompanying effect on insulin-stimulated glucose uptake with respect to both insulin sensitivity or responsiveness. This is in contrast to the results obtained in rat adipocytes where vanadate and $\mathrm{pV}$ can improve insulin sensitivity $[6,7,32]$, probably due to that in rat, but not human, adipocytes, vanadate and $\mathrm{pV}$ can enhance binding of insulin to cell surface receptors $[6,18]$. The discrepancy between the effects of $\mathrm{pV}$ on insulin-stimulated protein tyrosine phosphorylation and glucose uptake indicates that insulin-resistant glucose uptake in NIDDM is not merely caused by phosphotyrosinerelated mechanisms. If this was the case, insulin-stimulated glucose uptake would then be expected to improve in the presence of $\mathrm{bpV}$ (pic) leading to an enhanced tyrosine phosphorylation of the insulin receptor as well as other insulin signalling peptides including IRS-1. This also supports the concept of spare capacity in tyrosine kinase activity [18, 30]. However, the effect of $\mathrm{pV}$ on protein tyrosine phosphorylation seems to be much less specific compared with that of insulin. Possibly, the tyrosine phosphorylation of some of the proteins that become phosphorylated in response to $\mathrm{bpV}$ (pic) may attenuate the insulin signal and its effect on glucose uptake. In addition, other mechanisms such as the total number of GLUT4 glucose transporters [29] and their functional insertion in the plasma membrane [33] may be critical for the regulation of glucose uptake in diabetic adipocytes.

In summary, the present study on adipocytes from NIDDM patients shows that lipolysis in response to $\beta$-adrenergic stimulation was impaired probably due to defects distal to the formation of cAMP. The peroxovanadium compound bpV(pic) displayed clear insulin-like effects on lipolysis and glucose uptake. Although tyrosine phosphorylation of insulin signalling proteins was markedly increased by $b p V($ pic), its effect on glucose uptake was impaired in NIDDM cells and low concentrations of $\mathrm{bpV}$ (pic) did not improve insulin sensitivity suggesting that insulin-resistant glucose uptake in NIDDM is not merely caused by perturbation in tyrosine kinase activity and subsequent tyrosine phosphorylation.
A cknowledgements. This study was supported by the NovoNordisk, Magnus Bergwall, Tore Nilson and Elsa and Folke Sahlberg Foundations, the Swedish Diabetes Association, the Göteborg Diabetes Association and the Swedish Institute.

\section{References}

1. Shechter Y (1990) Insulin-mimetic effects of vanadate. Possible implications for future treatment of diabetes. Diabetes 39: $1-5$

2. Cam MC, Pederson RA, Brownsey RW, McNeill JH (1993) Long-term effectiveness of oral vanadyl sulphate in streptozotocin-diabetic rats. Diabetologia 36: 218-224

3. Heyliger CE, Tahiliant AG, McNeill JH (1985) Effect of vanadate on elevated blood glucose and depressed cardiac performance of diabetic rats. Science 227: 1474-1476

4. Halberstam M, Cohen N, Shlimovich P, Rossetti L, Shamoon H (1996) Oral vanadyl sulfate improves insulin sensitivity in NIDDM but not in obese nondiabetic subjects. Diabetes 45: 659-666

5. Shisheva A, Shechter Y (1993) Mechanism of pervanadate stimulation and potentiation of insulin-activated glucose transport in rat adipocytes: dissociation from vanadate effect. Endocrinology 133: 1562-1568

6. Yu Z-W, Posner BI, Smith U, Eriksson JW (1996) Effects of vanadate and peroxovanadate on insulin binding, degradation and sensitivity in rat adipocytes. Biochim Biophys Acta 1310: 103-109

7. Eriksson JW, Lönnroth P, Smith U (1992) Vanadate increases cell surface insulin binding and improves insulin sensitivity in both normal and insulin-resistant rat adipocytes. Diabetologia 35: 510-516

8. Posner BI, Faure R, Burgess JW, et al. (1994) Peroxovanadium compounds: a new class of potent phosphotyrosine phosphatase inhibitors which are insulin mimetics. J Biol Chem 269: 4596-4604

9. Bernier M, Larid DM, Lane MD (1988) Effect of vanadate on the cellular accumulation of pp15, an apparent product of insulin receptor tyrosine kinase action. J Biol Chem 263: $13625-13634$

10. Lönnroth P, Eriksson JW, Posner BI, Smith U (1993) Peroxovanadate but not vanadate exerts insulin-like effects in human adipocytes. Diabetologia 36: 113-116

11. Reaven GM (1988) Role of insulin resistance in human disease. Diabetes 37: 1595-1607

12. Arner P, Bolinder J, Engfeldt P, Östman J (1980) The antilipolytic effect of insulin in human adipose tissue in obesity, diabetes mellitus, hyperinsulinemia, and starvation. Metabolism 30: 753-760

13. Shechter Y (1984) Trifluoperazine inhibits insulin action on glucose metabolism in fat cells without affecting inhibition of lipolysis. Proc Natl Acad Sci USA 81: 327-331

14. Howard BV, Savage PJ, Nagulesparan M, Bennion LJ, Unger RH, Bennett PH (1979) Evidence for marked sensitivity to the antilipolytic action of insulin in obese maturityonset diabetics. Metabolism 28: 744-750

15. Foley JE, Kashiwagi A, Verso MA, Reaven G, Andrews J (1983) Improvement in in vitro insulin action after one month of insulin therapy in obese noninsulin-dependent diabetics: measurements of glucose transport and metabolism, insulin binding, and lipolysis in isolated adipocytes. $\mathbf{J}$ Clin Invest 72: 1901-1909

16. Lönnroth P, Digirolamo M, Krotkiewski M, Smith U (1983) Insulin binding and responsiveness in fat cells from patients 
with reduced glucose tolerance and type II diabetes. Diabetes 32: 748-754

17. Olefsky JM (1993) Insulin resistance and the pathogenesis of non-insulin dependent diabetes mellitus: cellular and molecular mechanisms. In: Östenson CG, Efendic S, Vranic M (eds) New concepts in the pathogenesis of NIDDM. Plenum Press, New York, pp 129-150

18. Eriksson JW, Lönnroth P, Posner BI, Shaver A, Wesslau C, Smith UPG (1996) A stable peroxovanadium compound with insulin-like action in human fat cells. Diabetologia 39: $235-242$

19. Smith U, Sjöström L, Björntorp P (1972) Comparison of two methods for determining human adipose cell size. J Lipid Res 13: 822-824

20. Bradley DC, Kaslow HR (1989) Radiometric assays for glycerol, glucose, and glycogen. Anal Biochem 180: 11-16

21. Lafontan M, Berlan M (1993) Fat cell adrenergic receptors and the control of white and brown fat cell function. J Lipid Res 34: 1057-1091

22. Reynisdottir S, Ellerfeldt K, Wahrenberg H, Lithell H, Arner P (1994) Multiple lipolysis defects in the insulin resistance (metabolic) syndrome. J Clin Invest 93: 2590-2599

23. Reynisdottir S, Eriksson M, Angelin B, Arner P (1995) Impaired activation of adipocyte lipolysis in familial combined hyperlipidaemia. J Clin Invest 95: 2161-2169

24. Ueki H, Okuhama R, Sera M, Inoue T, Tominaga N, Morita T (1992) Stimulatory effect of vanadate on $3^{\prime}, 5^{\prime}$-cyclic guanosine monophosphate-inhibited low Michaelis-Menten constant $3^{\prime}, 5^{\prime}$-cyclic adenosine monophosphate phosphodiesterase activity in isolated rat fat pads. Endocrinology 131: 441-446

25. Lönnroth P, Smith U (1986) The antilipolytic effect of insulin in human adipocytes requires activation of the phosphodiesterase. Biochem Biophys Res Commun 141: 1157-1161

26. Manganiello VC, Smith CJ, Degerman E, Vasta V, Tornqvist H, Belfrage P (1991) Molecular mechanisms involved in the antilipolytic action of insulin: phosphorylation and activation of a particulate adipocyte cAMP phosphodiesterase. In: Raizada MK, LeRoith D (eds) Molecular biology and physiology of insulin and insulin-like growth factors. Plenum Press, New York, pp 239-248

27. Yki-Järvinen H, Taskinen M-R (1988) Interrelationships among insulin's antilipolytic and glucoregulatory effects and plasma triglycerides in nondiabetic and diabetic patients with endogenous hypertriglyceridemia. Diabetes 37: 1271-1278

28. Smith U, Lager I (1989) Insulin-antagonistic effects of counterregulatory hormones: clinical and mechanistic aspects. Diabetes Metab Rev 5: 511-525

29. Garvey WT, Maianu L, Huecksteadt TP, Birnbaum MJ, Molina JM, Ciaraldi TP (1991) Pretranslational suppression of a glucose transporter protein causes insulin resistance in adipocytes from patients with non-insulin-dependent diabetes mellitus and obesity. J Clin Invest 87: 10721081

30. Thies RS, Molina JM, Ciaraldi TP, Freidenberg GR, Olefsky JM (1990) Insulin-receptor autophosphorylation and endogenous substrate phosphorylation in human adipocytes from control, obese, and NIDDM subjects. Diabetes 39: $250-259$

31. Sinha MK, Pories WJ, Flickinger EG, Meelheim D, Caro JF (1987) Insulin-receptor kinase activity of adipose tissue from morbidly obese humans with and without NIDDM. Diabetes 36: 620-625

32. Yu Z-W, Wickman A, Eriksson JW (1996) Cryptic receptors for insulin-like growth factor II in the plasma membrane in rat adipocytes - a possible link to cellular insulin resistance. Biochim Biophys Acta 1282: 57-62

33. Vannucci SJ, Nishimura H, Satoh S, Cushman SW, Holman GD, Simpson IA (1992) Cell surface accessibility of GLUT4 glucose transporters in insulin-stimulated rat adipose cells: modulation by isoprenaline and adenosine. Biochem J 288: 325-330 